\title{
Corporate Social Responsibility: One Size Does Not Fit All. Collecting Evidence from Europe
}

\author{
Antonio Argandoña \\ Heidi von Weltzien Hoivik
}

\begin{abstract}
This article serves as an introduction to the collection of papers in this monographic issue on "What the European tradition can teach about Corporate Social Responsibility" and presents the rationale and the main hypotheses of the project. We maintain that corporate social responsibility (CSR) is an ethical concept, that the demands for socially responsible actions have been around since before the Industrial Revolution and that companies have responded to them, especially in Europe, and that the content of CSR has evolved over time, depending on historical, cultural, political, and socio-economic drivers and particular conditions in different countries and also at different points in time. Therefore, there is not - and probably cannot be - a unique, precise definition of CSR: one global standard for CSR is unlikely.
\end{abstract}

KEY WORDS: Business ethics, corporate social responsibility, Europe, responsibility, United States, welfare state

Antonio Argandoña is Professor of Economics and 'la Caixa' Chair of Corporate Social Responsibility and Corporate Governance at IESE Business School, University of Navara. A member of the Royal Academy of Economics and Finance, he has been the Honorary Treasurer of the European Business Ethics Network (EBEN), and founder and Secretary General of EBEN Spain. He is the author and editor of many books and articles on economic and business ethics.

Heidi von Weltzien Hoivik is Professor of Business Ethics and Leadership at the Norwegian School of Management. A Fellow of the Harvard Executive Program of the Institute of Education Management, and a Fellow of the Harvard Program on International Negotiations, she has served as executive member of the Caux Round Table, of Transparency International Norway, and of the International Society for Business, Economics and Ethics (ISBEE). For 8 years, she was president for the European Business Ethics Network (EBEN) and was honored for her work with an honorary doctorate degree.

\section{Introduction}

This article has three purposes. First, it serves as an introduction to the collection of papers in this monographic issue of the Journal of Business Ethics. Second, it gives the rationale for why this project was and is being undertaken, in spite of the existing vast literature on corporate social responsibility (CSR). And third, it presents the main hypotheses of the project and their justification. The genesis of this project came about in December 2005 when both authors attended the Fourth Annual Colloquium of EABIS, the European Academy of Business in Society, in Warsaw. We agreed that the concept of CSR as a management idea essentially is nothing new, even though it is often presented as such. Furthermore, if implementation of CSR is only presented as an (other) instrument to achieve and secure "a license to operate" and to remain in good standing in the public eye, some very essential core elements are being overlooked.

One finds multiple definitions of CSR both in academic papers, company reports and political documents. This is not only confusing, but an indication of the inherent weakness of the concept. Yet, there is no consensus when it comes to defining CSR. Traditionally, we distinguish three types of responsibility: economic, social, and environmental (Carroll, 1979). This is a practical distinction, aimed at helping managers to organize work and information; however, it does not properly reflect all that CSR can entail. And, in particular, a discussion and explanation of strictly European perspectives and definitions is lacking. In the US, around the midtwentieth century, the scattered ideas that business owes something to society beyond seeking profits 
were drawn together into a doctrine (Frederick, 2006), and the term was coined, emphasizing fairness, justice, and dignity. In Europe, the developments were altogether different and more diversified.

We hold that the cause of the obvious absence of consensus around one definition of CSR is not a lack of ingenuity or capacity of the experts: it can also be traced back to the different origins of this age-old concept where historical, cultural, and socio-economic factors, besides language, have been and still are playing a decisive role. In some countries, for example, Scandinavia, the term "social" is translated into "societal," thus signaling a shift of focus to macro economic conditions (this is documented in several papers of this special issue: see Berthoin Antal et al., 2010; De Geer et al., 2010; Waldkirch et al., 2010).

Matten and Moon (2008, p. 405) best highlighted the heterogeneity of the definitions of CSR in the following manner: "CSR is an umbrella term overlapping with some, and being synonymous with other, conceptions of business-society relation." We think that the main problem when trying to pin down the concept of CSR is the lack of integration among its parts, possibly due to different views of the role of the firm in society. In this article, we offer a different approach by refocusing on the core elements of social responsibility.

We agreed on the following working hypotheses for the project:

Hypothesis 1: Corporate social responsibility is an ethical concept.

Hypothesis 2: The demands for socially responsible actions have been around since before the Industrial Revolution, and firms have usually responded to them.

Hypothesis 3: The content of Corporate Social Responsibility has evolved over time, depending on historical, cultural, political, and socio-economic drivers and particular conditions in different countries and also at different points in time. One global CSR standard is, therefore, unlikely.

Based on these deliberations, the project emerged with the provisional title "Re-visiting social and ethical issues in business - a historical perspective of the development in Europe." It materialized in a call for papers for a special session at two EBEN Annual Conferences in 2007 and 2008. The authors felt that the debate around the role of business in society and CSR had lost the link to business ethics. The many efforts of companies and consultants - who were leading the way, while academics mainly observed developed technical and practical recommendations which, though very useful for companies, also significantly narrowed the scope of CSR and severed it from its ethical roots.

Against this background, we felt it was important to invite experts in business, social ethics, and other disciplines to help us broaden the scope by reflecting on the roots and traditions of social responsibility in Europe. We expected and received a very eclectic response to the call for papers. The special sessions at the conferences yielded a broad discussion and helped us to narrow down the number of papers for this special issue. It would be pretentious on our part to claim that this is the final phase of the project. We are more than ever convinced that this truly has to be work in progress. However, it was not advisable to delay the publication of these papers any longer, especially out of respect to the authors of the selected articles.

We wish to emphasize that the call for papers provided ample freedom to the authors and that they were not asked to identify themselves with our ideas for this project, nor do they have to agree with the positions we are taking in this article. Furthermore, each article has its proper theory and content and is independent of the hypotheses mentioned by us. Yet, some of our hypotheses were confirmed to some degree while others remain open to further investigations.

In the following sections, we briefly develop the ideas behind our hypotheses and proceed by linking them to some ideas developed in the articles published in this special issue. Finally we offer the conclusions.

Hypothesis 1: Corporate social responsibility is an ethical concept.

Corporate social responsibility means different things to different people. We do not believe in "fundamentalism" of definitions: people will use them the way they want. However, we think that if we want to know what we are talking about, it is important to agree on a basic understanding of the words. This is why we propose to reflect first on what we consider 
to be the very core of CSR, namely the concept of "responsibility," and afterward its social dimension i.e., the "R" and the "S" of CSR.

\section{Moral responsibilities}

A common definition of "responsibility" is the state or trait of "being responsible; being accountable," i.e., "legally of morally liable for carrying out a duty, for the care of something or somebody." sibility is, therefore, either a legal or a moral category - and in the case of CSR, it is a moral one. " "To say that a person is responsible (...) for a given action is only to say that it is appropriate to take it as a basis of moral appraisal of that person" (Scanlon, 1998, p. 248). As such, it is part of every human action: only people and their actions can be subject to moral evaluation; but corporations are made of people, and thus their actions can be evaluated morally too.

We hold that this ethical dimension is present in the majority of definitions of CSR, although frequently in an implicit way, by expressions like "commitment by businesses to manage their roles in society" (International Chamber of Commerce, 2002), "to contribute to a better society and a cleaner environment" (European Commission, 2001), "the management of a company's positive impact on society and the environment" (Business in the Community, n.d.) or simply "doing the right thing even when no-one is looking" (Anonymous, 2006, cited by Thomas and Nowak, 2006, p. 17). Of course, CSR must be translated into organizational settings and management systems to demonstrate compliance, reduce risks and potential liabilities, show due diligence to interested stakeholders, and achieve its objectives. However, CSR is not primarily a management tool: it is, first, "doing the right things," that can afterward be translated into "doing things right" and "continuous improvement and innovation" (Zwetsloot, 2003).

The role of responsibility in business ethics has been well explained. ${ }^{4}$ Nevertheless, the books, articles, and papers on CSR usually do not explain what do we mean when we say that a corporation or a firm is "responsible" for something (an action or an omission and its consequences); what is meant by responsibility "towards others," or what do we mean when we say "being responsible on behalf of someone," like a manager is responsible on behalf of the owners or of other stakeholders. ${ }^{5}$ What does the " $R$ " in CSR mean? We can identify four aspects:

(1) Responsibility as attribution. Responsibility appears when an action and its effects are attributed to a person not only as the cause of the action (causal responsibility), but as a "moral agent." This attribution or assumption can be done by the agent herself or by a third person. In the first case, the agent acknowledges herself as capable of acting and conscious of what she is doing, as when we say that the driver of a vehicle is responsible for a traffic accident, independently of other possible contributing factors. ${ }^{6}$ From this viewpoint, responsibility is part of the virtue of prudence. It is retrospective or a posteriori: the agent acted (or failed to act) in the past, and the resulting moral responsibility for the action and its consequences is attributed to her. ${ }^{7}$

If it is another person who observes the action and attributes responsibility to the agent, he or she will judge that the agent has satisfied the conditions to be responsible, and this judgment will elicit a reaction, such as approval, praise, rejection, or repulsion, in the observer. ${ }^{8}$

(2) Responsibility as a duty. For example, when we say that a driver has the responsibility or obligation of driving carefully so as not to cause any damage to himself, other people, or their property. In fact, this is what we mean when we say that a person "acts responsibly": that we can be confident that he will judge and act in an ethically desirable way. This responsibility is a prospective (Jonas, 1984) or a priori and creates duties for the present or the future - and from this viewpoint responsibility forms part of the virtue of justice.

Responsibility as an obligation presupposes responsibility as an attribution and gives rise to a duty to use the means that are necessary or appropriate to meet the obligation. It also presupposes a willingness to shoulder the consequences, including compensation for any damage that may have been caused - and here ethical responsibility links with 
legal responsibility. And all this is capable of gradation, from the indispensable minimum so as not to cause serious damage to other people to full and generous compliance even beyond what is strictly required. Responsibility understood as a duty uses to be related to the agent's social or legal role: a manager has a responsibility or duty to prevent employees being injured at work. ${ }^{9}$

(3) Responsibility as responsiveness. The agent's response to prospective responsibility leads to responsibility as a disposition: the agent's sensitivity or willingness to respond to the needs or demands of others. It is founded on a person's ability to make genuine moral decisions for himself, so that he can be relied upon to meet his obligations and accept the consequences of his acts.

Responsibility lived as something continuous and enduring implies both awareness and consistency: the moral agent is not only responsible for her actions but also, above all, for seeing and creating the conditions (virtues) that will enable her to live in accordance with that responsibility at all times. Responsibility includes past and present actions and future projects, including the conditions that the person creates when making the decision and which will determine its outcome - in other words, to some extent, her entire biography - the reasonably foreseeable consequences and those that, although they have not been considered, arise from her decision, in the personal, interpersonal, and social sphere (of course, with varying degrees of responsibility). This is not only true for persons but also for firms as well.

(4) Responsibility as accountability or answerability. It is a consequence of responsibility as attribution: the moral agent is capable of accounting of and for her action or omission, and accepts its consequences (including those not foreseen). ${ }^{10}$ She must account not only for what she does, but also for the moral reasons for why that justifies the action. In the eyes of others, this means that the moral agent is seen as trustworthy.

Responsibility as accountability is social, owed to another person or a community. It is subject to the normative standards required of interpersonal behavior and to external scrutiny, evaluation and sanction; it implies duties of disclosure and transparency and accepting the supervision of those to whom one is accountable: ${ }^{11}$ it is accounting "towards others or in terms of some shared sense of normative propriety" (Painter-Morland, 2006, p. 93; emphasis in the original). Responsibility as such implies a certain right, a legal, moral or social authority, or at least a moral community to which the agent and those to whom he is accountable belong (Eshleman, 2004). The results are praise or censure for the agent's conduct, as well as an inner feeling of guilt or satisfaction which the agent experiences (Fisher and Ravizza, 1998; Glover, 1970; Wallace, 1994).

Attribution, duty, responsiveness, and accountability are four complementary aspects of responsibility. A responsible agent accepts her responsibility for its past actions and omissions and her duties for future actions, and assumes the disposition to respond to these duties, to put the means to behave accordingly and to give account of them.

\section{Social responsibilities}

Any firm is the subject of many social responsibilities. As a first approximation, the CSR of a firm includes all these moral (and legal) responsibilities towards other people, its internal (shareholders, managers, and employees) and external (clients, consumers, suppliers, the local community, other groups of interest, and the whole society) stakeholders. Of course, CSR is more than this: it includes strategies, policies, tools, standards, etc., but we think that CSR is, first of all, neither a strategy (although it must be included in the strategy of the company) nor a set of management tools, reports, audits, etc.: all these are tools for putting CSR into practice.

According to this viewpoint, the first reason for a firm to be responsible must be that this is its ethical duty, beyond any other argument or advantage, either material or reputational. And the content of a firm's CSR must be the result of the reflection of its owners and managers on its relationships with stakeholders - and as we will show later this has been the practice of many companies in the past. ${ }^{12}$

However, this ethical reflection cannot be a closed, inward-looking exercise: moral agency is "a thoroughly relational affair" (Painter-Morland, 2006, 
p. 90). When one agent accepts that he or she has some responsibilities, other people develop expectations toward the behavior of the agent. This is why we sometimes say that CSR is a response of the firm to the demands and expectations of society (Carroll, 1979). However, what does it mean that the firm has a responsibility toward society - what is the meaning of the " $\mathrm{S}$ " in CSR?

First, society can act as a wake-up call to the conscience of the owners, managers, and employees, confronting them with the firm's responsibilities. And secondly, society can specify the ethical obligations of the firm: for example, the duty not to discriminate against an employee will be specified differently in different societies, although the norm "do not discriminate" will be general and morally binding. This perception of the role of society in the definition of the firm's CSR strengthens the argument, that we will discuss later, that the company understands its social responsibilities as they evolve as social practices in different cultures at different times, in line with Pava's (2008) claim that, in a dynamic and highly interdependent world, accountability is no longer fixed and pre-determined, but fluid and constantly changing.

However, the concept of CSR as an answer to the expectations and demands of society can have another interpretation. Strawson (1962) maintained that we are not able to make ethical judgments about someone being responsible; our reactive attitudes (approval, repulsion) when we judge the responsibility of other people are a natural expression of an essential feature of our interpersonal form of life, and our judgments about the appropriateness of their actions refer to an account of our reactions, not to an external, "rational" justification. In short, the social responsibilities of the firms are not supported by ethical duties, but by the "social practice" of holding them responsible (Eshleman, 2004, p. 8).

This conception of CSR as a social practice is frequent. According to it, the duties of CSR would be merely "relational" (they would be molded in the complex web of relationships in which the firm participates) or "attached" (society simply would attach some duties to the firm, as a matter of fact). However, this attachment can be arbitrary, unjust or even immoral, because of the nature of what society demands, or because the society's expectations place an unfair burden on the firm. In the last analysis, the social responsibilities so understood would be accepted either from some kind of social pressure (as a unwarranted cost) or for practical reasons (to avoid blame or social rejection); and they will be no more "obligatory" than the cost-benefit calculation a person might make in deciding whether or not to wear formal dress to a business meeting. And we believe this to be the case if we understand CSR as a set of management tools, but not as a commitment to do what is good that is common in the usual definitions of CSR.

\section{Corporate social responsibility}

Therefore, from the point of view of the firm, its CSR is the set of moral duties towards other social actors and towards society that the firm assumes as a result of its economic, social, political, and, of course, ethical reflection on its role in society and on its relationships with those other actors. And with regard to external observers, it is the set of moral duties that the other agents and society attribute to the firm as a consequence of the role it assumes and its relationships with those actors. In practice, then, CSR will be the result of a dialog between the firm and its stakeholders about the obligations of the first and the expectations of the second.

These responsibilities are, as we said before, retrospective (for previous actions or omissions) and prospective (for future behavior), and include the disposition to act in this way (responsiveness) and to give account for these actions precisely to the society or community in which they act. This means that accountability contributes to a more precise definition of the scope in which CSR is exercised: it is owed to some people or communities and not to others, and it arises within a community, in accordance with the community's norms. The exercise of this responsibility and accountability is therefore both conditional and relative: it evolves over time and changes from one community to another and even within the same community. In the words of Painter-Morland (2006, p. 94), "the actions and responses of individuals and organizations cannot adequately be appreciated or evaluated without considering the specific business episode and context within which it is situated and of which it is a part. Accountability, from this perspective, is all about 
being responsive towards ever-changing stakeholder interests. It entails responding to these interests in terms of an evolving sense of moral appropriateness that has to be nurtured within everyday business practice." 13 We will elaborate on this when discussing the third hypothesis.

Hypothesis 2: The demands for and practices of social responsibility have been around since before the Industrial Revolution, and firms have usually responded to them.

The first part of this hypothesis, the demand for the social action of firms, is obvious: society has always asked companies to be responsible in many different ways - or, at least, firms have felt questioned by society. And we think that there is evidence for the second part when looking at how many companies in the past carried out actions which we can label CSR. Four articles published in this special issue are good examples: Waldkirch et al. (2010) present the case of Jakob Fugger II the Rich in Germany during the sixteenth century; Argandoña et al. (2010a, b) explain the creation and growth of the Caja de Pensiones para la Vejez $y$ de Ahorros in Spain in the beginning of the twentieth century; while Berthoin Antal et al. (2010) explain that "although the term "corporate social responsibility' (CSR) was not part of the German vocabulary, socially responsible practices were expected and these expectations were generally met."

Our hypothesis also supposes that managers assume their social responsibilities to be something which is demanded not (only) by the solicitations of stakeholders or society, but by the nature and the social function of the firm as its owners, managers, and employees understand it. ${ }^{14}$ We hold that the responsibilities a company assumes originate, first, from a reflection on how it sees itself (what are its aims, who are its internal stakeholders, how does it conceive its own structure and organization); second, what are its relations to society (in whose service does it act, who are its external stakeholders and what role does it give itself in relation to society) $;{ }^{15}$ and third, from the external demands and expectations of its stakeholders (although these demands could be the opportunity for the company to reflect on its responsibilities).

We do not have many proofs of this hypothesis, but Argandoña et al. $(2010 \mathrm{a}, \mathrm{b})$ show that the founders and managers of a savings bank in Spain in the first years of the twentieth century carried out this exercise. And we also believe that such a reflection is the origin of the (sometimes implicit) mission statements of many companies.

Hypothesis 3: The content of Corporate Social Responsibility has evolved over time, depending on historical, cultural, political and socio-economic drivers and conditions in different countries and also at different points in time. One global standard is, therefore, unlikely.

This hypothesis is, in some ways, a consequence of the previous one. When managers consider the role of their companies in society, its mission and what responsibilities entail in relation to their internal and external stakeholders, they do not start from an abstract model, but from the framework in which they find themselves. This framework consists of a vast collection of factors: geographical, social, political, cultural, ideological, philosophical, scientific, religious, etc. These factors vary from one place to another and change over time - also because of either active or passive behavior of the managers and power structures: "The relations between business and society are defined in different ways according to the historical, socio-economic and legal context and the powers of the relevant actors" (Berthoin Antal et al., 2010). For that reason, the identification of a company's responsibilities regarding its internal and external stakeholders will be strongly conditioned and even determined by this context.

As noted before, Waldkirch et al. (2010) show how a businessman, Jakob Fugger II, started a housing program for the poor, influenced by the ideas of the time and by the demographical, social, and economical changes that were in progress. Businesses, as well as some civil society institutions (cooperatives, guilds, churches, and local governments) assumed welfare-state-like actions, as part of their social responsibility, long before any government assumed this task. These authors also show how societal responsibilities of companies changed as consequence of new legislation imposed by the welfare state in the era of Prussia's Chancellor Bismarck, and again after the Second World War - and even now, in the first years of the twenty-first century - further modifications are necessary because of changes caused by globalization. 
The role of the social, cultural, political, economical, and ideological environments in the configuration of the social responsibility of businesses is also made evident in the papers of Argandoña et al. (2010a, b). The creation of the Caja de Pensiones para la Vejez $y$ de Ahorros and the social responsibility which its founder attributed to it cannot be understood outside of the Spanish setting of the early twentieth century. For our project, it is particularly important to understand the social ethics that inspired its founder, with its roots in religion (the philosopher Jaime Balmes), society (the French movement Economie Sociale), and politics (the "regeneration" movement that flourished in Spain as a consequence of the war with the United States and the colonies, 1895-1898), as well as the importance of a concrete event, the general strike in February 1902, whose consequences drove the creators of the savings bank to convert their project into reality.

Several authors of the articles in this issue also call our attention to the drivers or prescriptors of the changes in the content of CSR. In Rusconi and Signori (2010), those prescriptors were the scholars; in Argandoña et al. (2010a, b), they were the entrepreneurs, but undoubtedly influenced by scholars, philosophers, and political reformers; in Waldkirch et al. (2010), this task was performed in the past by businessmen (Jakob Fugger II) and politicians (Bismarck, Erhard), probably together with other promoters. We will comment further on the changes in the promoters of CSR in Sweden that De Geer et al. (2010) find in recent years.

A corollary of this hypothesis is that the development of CSR in the United States and in Europe has been and is different, because of the diversity of circumstances, as explained before, and especially because the firms' responsibility for social and environmental issues is viewed mainly as voluntary in an unregulated market in the US, and as intertwined with laws and government policies in Europe. This means that there has been, and remains, a big gap between both visions of CSR - and even it should be emphasized that there is not "a" European social model, but several: Anglo-Saxon, Central-European, Scandinavian or Nordic, Mediterranean, Central and Eastern European, etc., with remarkable differences between countries, because of their particular contexts. ${ }^{16}$

One consequence of this is that copying CSR models from one country to another will probably yield many problems or even end in failure - and forgetting this would probably mean reducing the unique potential of CSR. ${ }^{17}$ Another consequence is that the convergence of models is a dubious assumption.

Sison (2010, in this issue) highlights some of the characteristic features of the European framework of CSR when compared with the US: "Philosophically, Anglo-American culture may be described as individualistic, legalistic, pragmatist and with an understanding of rights as freedom from state intervention. Continental European culture, on the other hand, is more community-oriented, more dependent on unwritten laws or customs, less results-driven or more appreciative of the intrinsic value of activities and with an understanding of rights as freedom to participate in social goods and decisions". We can add other distinct features such as solidarity and cohesion (broader public health and pensions plans, and more developed social protection mechanisms, such as unemployment insurance), the right to participate in the discussion of work-related problems and decision making (co-determination in Germany, industrial democracy in Scandinavia, greater weight of trade unions in business and political decisions in many countries), less tolerance toward income inequality (a more developed welfare state, minimum wages, higher taxes) and higher quality of public goods (primary and secondary education, etc.). The US-Europe differences in CSR are likely to persist, and also the manner in which corporations address CSR issues, such as climate change or bringing democracy and economic improvement to the developing world (Doh and Guay, 2006).

Rusconi and Signori (2010) present yet another distinctly different European approach, this time from Italy. They relate the stakeholder management theory with the theories of the Economia Aziendale which were developed in that country by Gino Zappa and his disciples, Carlo Masini, Pietro Onida, and Aldo Amaduzzi, since the 1920s. Strictly speaking, the article is not about CSR, but about a theory of business (or even better, of the "organization" or the "azienda") ${ }^{18}$ with not only a strong economic content, but also ethical, humane, and social. The interest of this article for our project is that it presents a holistic conception of the company, its mission (the satisfaction of human needs), its unity (despite the changes in time), its call of continuance, its structures (as a community of individuals), its 
dimensions (economical, social and ethical: cf. also Argandoña et al., 2010a), the harmony of interests between stakeholders (the azienda as a mediating structure for the composition of diverging interests), its open character and connectedness with the socioeconomical surroundings, etc. ${ }^{19}$ And even though the authors of the Economia Aziendale did not speak of CSR, it is apparent that, based on this understanding of the company, these responsibilities were directed toward its internal and external stakeholders and toward society.

De Geer et al. (2010) contemplate a distinct framework in which the traditional Swedish "social actors" (employers, trade unions, and governments) have, throughout time, defined its identities and its social functions - and, logically, its responsibilities. What characterizes the Swedish model is the accomplishment of these functions and responsibilities in one national model, broadly accepted: the state assumes the provision of welfare services, the companies assume as their main responsibility the financing of those services through taxes, and both employers and unions assume the responsibility of setting the main economic variables and the adaptation and operation of the labor framework to the changing circumstances (frequently with the participation of the state).$^{20}$ In the context of our thesis, once the welfare state is defined with its components, principles, and rules of action, the social responsibility of companies is, in some way, also defined: the traditional welfare state "encounters, translates, and gives the worldwide idea of CSR a particular shape" (De Geer et al., 2010).

However, this is why the reception of the "new" concept of CSR is conflicting in Sweden and other countries (De Geer et al., 2010). First, it does not respond to the needs and interests of the traditional actors (government, employers, and unions), but it is a consequence of issues and problems that are not located in Sweden - globalization, human rights, the environment, deregulation, financial reform, etc. Second, it attracts academics, managers of multinational corporations, consultants, NGOs, media, and investors, but not necessarily the original actors in the Swedish model. ${ }^{21}$ And third, it is attentive toward principles which do not figure in the original agenda of the welfare state. The article by De Geer et al. (2010) articulates the possible duality of the concept of CSR, one being part of the welfare state in the traditional companies that operate in the country, and another, broader CSR for multinationals that work in other countries. The difficulty consists of maintaining a national social contract in a globalized, competitive, dynamic world where other economic and legal conditions exist.

Berthoin Antal et al. (2010) also pay attention to the acceptance of the concept of CSR in one country, Germany in this case. Once more, they keep the idea that social responsibilities, old or new, are defined in different ways depending on the context and power of relevant actors - in Germany, as a result of discussions and negotiations rather than the direct exercise of power. Also, here a variety of drivers emerge: utopian philosophers and social critics, philanthropists, religious and ethical thinkers, political and business interests. And as in Waldkirch et al. (2010) and De Geer et al. (2010), the institutionalization of the welfare state profoundly changes the approach to these responsibilities, displacing it from the private to the public sector. The result is the creation of a set of economic, social, and political duties that will crystallize in responsibilities established by a national agreement among the social partners (employers, labor unions, and the state as guarantor). ${ }^{22}$ In what has been labeled "organized capitalism" (Hiss, 2009, p. 435) in Germany, an implicit consensus has been forged that private interests could be made responsible for the common good. ${ }^{23}$ For this reason, CSR activities in Germany are deeply embedded in the view of the firm. And they are implicit: there is no need to verbalize them.

However, as the article of Berthoin Antal et al. (2010) shows, the situation in Germany is changing since the unification in 1990, due to external reasons such as pressure from the European Commission, and above all, due to what appears to be a failure of the previous model: issues like the unemployment growth, reduced job opportunities for youngsters, and the emergence of global environmental awareness highlight the lack of resources of the welfare state's corporatist model. And these problems cannot be solved by the division of functions between state, trade unions, and employers, but require the active participation of businesses and a change of attitude by the government (the "activating state": the State that actives the participation of other actors). ${ }^{24}$

We will add also that using the same words does not mean that we agree with its contents. As shown 
by De Geer et al. (2010), the acceptance of the term CSR by Swedish companies does not mean that its meaning is equal to that given in other countries.

\section{Conclusions}

The purpose of this article is to explain the rationale of a research project on "What the European tradition can teach about CSR" and to present the selected articles in this special issue. As anticipated, the degree of validation of our hypothesis is variable, making this an ongoing project. Nevertheless, we dare to present some conclusions, hoping also to stimulate further research and discussion.

The first conclusion is that there are many useful definitions of CSR, but there is not - and probably cannot be - a unique, precise definition of CSR, because its content and application will vary from one country to another, will change over time and also will differ among firms.

CSR is the result, implicit or explicit, of a reflection on the nature of a firm, its role in society and its relationships with its internal and external stakeholders. This reflection is not only the task of the managers (and sometimes of the owners), but also of other stakeholders who have an impact on the firm or are being impacted. The outcome will vary according to historical events, political systems, ideology, geography, social expectations and, as we have recently seen, global economic and financial pressures. Together this constitutes the framework in which a company operates and defines how it can and wants to develop its CSR policies.

We dare say that, because we live in a plural, diverse and changing world, it is not possible to reach a universal agreement on the concept of CSR because ideas and facts, philosophy and history, society and the environment are interrelated. Moreover, CSR is also a dynamic concept that will change over time, as we have experienced in recent decades (and not only because of experts' contribution).

Recently, we have observed that companies become social agents when taking on social and environmental responsibilities both at home and abroad. This may lead to a wider definition of the role of a firm in society, especially in view of globalization. However, this change does not necessarily mean that new definitions will supersede the old ones: new definitions may be an evolution, but it must not necessarily be so. The challenge is to resist the temptation to develop a unified standard of CSR, because such a standard would be devoid of richness, variation, and flexibility and, in view of the developing world, could likely be regarded as a new form of colonization through Western concepts. What we said of the differences between Europe and the United States can also be applied to many emerging economies: the fact that they have different views on CSR does not mean that those views are inferior.

We recognize that there are valid reasons for such a call for a unified standard: the use of common theoretical backgrounds by academicians and of common tools by consultants; the interest of the financial analysts in finding simple and comprehensive measures of CSR for companies in different environments; the sharing of experiences by CSR managers of different companies and their interest in finding common and universal metrics for assessing their results; the interest of the politicians in promoting state-of-the-art CSR instruments in their countries, and the preference of multinational corporations to find a level playing ground in the different places in which they do business. However, these reasons are not convincing: if CSR is an ethical concept, there is nothing that can replace prudent analysis of each decision. We cannot expect that two managers in different companies react the same way, even in the same sector, country, and time and if the problems look alike, when the histories and environments of their firms and their personal experiences, training and personalities are different. This is valid for every management situation and also for CSR decisions. There is no set of universal "best practices" in CSR.

The previous conclusions have many different implications. For example, as we explained earlier, it is only natural that there are unique differences between the Anglo-Saxon (American and British) and the European (Continental, Scandinavian, Mediterranean, Eastern European, etc.) models of CSR, even though there are also many common elements. It does not make sense to discuss which approach is best: they are different, because their settings are also different, and they will change, in part, because of changes in the environment, and also because of competition between models. We can compare two models, but there are obvious limitations when 
judging one of them with the criteria of the other, since a full translation is neither possible nor desirable. And this is also valid when judging previous models of CSR using present criteria. Even the use of the same words does not guarantee that we are comparing the same concepts: as we said before, in some European countries the term "social" in CSR is translated as "societal," because the first word has a limited meaning, as is the case in the Scandinavian countries. This is a caution against possible "imperialism" in the use of words, and also suggests that the use of English as a common language may sometimes be more of a difficulty than an advantage.

The collection of papers in this special issue gives evidence for the claim that also in Europe the demands for and practices of CSR have been around since before the Industrial Revolution. They are a part of the normal activities of business, not something newly added in recent years. Companies cannot disregard them: even when they say that their only goal is maximizing profits, they are formulating a statement about their responsibility toward stakeholders and society, though very limited. CSR is an integral part of a firm's strategy and its competitiveness and must continue to be highly diversified, even firm specific, in order to be successful.

We held also that CSR is mainly an ethical concept and even if there are other "managerial" dimensions, we cannot forget that "to be responsible" is a moral category. ${ }^{25}$ CSR is, then, neither an exercise of costs and benefits, of merely behaving according to the more or less arbitrary expectations and demands of society or of the different stakeholders, nor a management tool, nor even a mere social practice. Every decision in a company has a relational dimension, but we do not think that there is a "relational responsibility," meaning a responsibility attributed by society to the behavior of firms. We think that such a relational responsibility would open the door to an arbitrary attachment of responsibilities for political, ideological or private, even immoral, reasons.

We also think that when understanding social responsibilities as a mere response to the demands and expectations of society and not as ethical duties, it opens the door to a tick-the-box mentality. As the theories of incentives and control show, such a mentality provokes undesired effects, hinders ethical practices and even affects the socially expected behavior of the firm. This instrumental, "making the business case" thinking about CSR has led to a variety of arguments claiming that it is profitable for businesses to engage in CSR in order to improve the bottom line. However, the many attempts to measure corporate social performance in order to make a connection between CSR and financial performance have not yielded any convincing results; they remain inconclusive (Vogel, 2005).

We think that the ultimate reasons to be responsible are not external results for employees, consumers or society, but the inherent moral quality of the persons and of the organization. To show that to be a social responsible manager is, in the last analysis, to be a good manager could be the strongest reason to win the support of managers and experts for CSR. Unfortunately, we are still far away from this, and the fear of many managers regarding ethics, still often understood as an external imposition on a profit-maximizing behavior, remains a big hurdle. They prefer a tick-the-box CSR or a list of obligations that managers can bargain with the other stakeholders.

Saying that social responsibilities of a company are of an ethical nature does not contradict the fact that the scope and content of CSR changes along time and throughout places. It is the same relationships that we find between ethical principles and its application in specific settings: many ethical schools will recognize that the firms have duties toward the environment, but the detailed content of these duties will not be the same in the US, China, or Germany, or in any of these countries in the twenty-first century and one hundred years ago, or in a small rural area and in a big city, or in a chemical factory and in a travel agency. This is not ethical relativism.

And this argument helps us to understand the "social" nature of CSR: it is a responsibility that emerges in society, cannot be understood without the reference to this specific society (or societies), and needs the continuous interaction and dialog between the firm and its stakeholders (including the academia and the practitioners). As we said before, the role of a firm in society and, then, its social responsibilities cannot be defined in a vacuum. And this definition will depend on the responsibilities of all agents in society: governments, politicians, trade unions, non-governmental organizations, consumers, etc. When we define CSR, we are implicitly 
defining the whole set of interrelated responsibilities and roles in society: CSR is not only business ethics, but also social ethics and even political ethics, and besides the corporate responsibilities there are also the responsibilities of government, public administration, trade unions, the media, consumers, etc. It is tempting to add that this observation leads us automatically to view firms not only as economic actors but also as political agents. In particular, the changing interplay between state and private actors locally and when doing business globally requires rethinking. The new political role of firms emerging globally challenges both business managers and academics to reflect on how the core of ethical social responsibility can be sustained. We challenge the research community to address these issues further.

\section{Notes}

1 In this article, we avoid any discussion of the advantages or drawbacks of the use of terms like corporate social responsibility, corporate responsibility, social responsibility, corporate citizenship, corporate responsiveness, and many others that have been suggested in the literature. We explicitly use corporate social responsibility or CSR as an "umbrella word" that presumably covers all of them.

2 According to the Oxford Advanced Learner's Dictionary of Current English.

3 Both responsibilities are related, but they do not necessarily coincide, either in its origin or in its scope. As CSR is usually understood as voluntary, we will not discuss legal responsibilities, although they are also a part of the broad responsibilities of business.

4 See, for example, the discussion of moral responsibility in De George (1982, ch. 5).

5 For general discussions of the concept of responsibility, see Eshleman (2004), Hart (1968), and Williams (2006).

6 The classic reference is Watson (1996); cf. also Weber (1921), on a person's availability to answer for the foreseeable consequences of her actions. As Pereboom (1999, p. 10) says, "for an agent to be morally responsible for an action, the action must truly belong to the agent" (cited in Fischer, 1999, p. 96).

7 For this attribution of moral responsibility to occur, two conditions usually have to be met. First, the action must be voluntary, that is, it must meet certain conditions of awareness and consent, and also of freedom: the agent knew what she was doing, she knew (or should have known) the foreseeable consequences, and she was not "forced" to act as she did. All of which implies that she wanted those consequences (she had the intention of obtaining those consequences), or at least accepted and allowed them, or else rejected them but still went ahead and performed or allowed the action to occur (De George, 1982; Takala and Pallab, 2000). These conditions were stated originally by Aristotle (1985). In any case, the conditions of awareness and consent do not have to be met perfectly, which implies that there can be different degrees of moral responsibility. And, second, there must be a moral norm or principle, explicit or implicit, to which the action must adhere and against which it may be judged.

8 In a now classic article, Strawson (1962) highlighted these "reactive attitudes." On responsibility from the point of view of the observer, see Fischer (1999), Smith (2007), and Wallace (1994).

9 There are also some responsibilities that are duties for everybody - for example, those related to basic human rights.

10 See Oshana (1997) for a classic discussion of moral responsibility as accountability.

11 In this, it differs from responsibility as an attribution, which exists no matter to whom the agent is responsible. Thus, responsibility as an attribution is linked to a person's intentions (in some ethical theories, at least), whereas social responsibility is not always, because society cannot judge intentions.

12 This leads us to the discussion of the nature of the moral agency of the firm, which we will not develop here.

13 The risk of CSR as a closed set of "objective" behavioral guidelines is that it "often leads to a checkthe-box mentality. In the process, the existence of compliance measures and reporting practices is mistaken for ethical responsibility" (Painter-Morland, 2006, p. 91).

14 Responsibilities in view of internal stakeholders are common to human organizations in general, and those assumed in view of external stakeholders come first from the social function of the firm and then on how the company specifies this function in each case (Argandoña, 2009).

15 Pérez López (1993) called this the "external mission" (what needs of which persons it will attend to) and the "internal mission" (how the internal stakeholders perceive the firm's external mission).

${ }_{16}$ There are many papers on the specifically European characters of CSR, especially when in contrast with the Anglo-Saxon or North American model (and also with other regional models: Asia, Africa, Latin America, etc.); for example: Adams et al. (1998), Habisch et al. (2005), Maignan and Ralston (2002), Matten and Moon 
(2008), Midttun et al. (2006), and Welford (2003, 2005).

17 We think that this claim is consistent with the viewpoints of De Geer et al. (2010), Waldkirch et al. (2010), and Berthoin Antal et al. (2010).

18 The fact that the concept of azienda is broader than company (which is why we translate it as "organization," even though this is not the term used by Rusconi and Signori) implies that CSR is not merely "corporate" or business, but concerns any human organization that coordinates individual actions for the achievement of objectives in which all members of the organization are interested, although the reasons why the wish them may be very different (Pérez López, 1993).

19 Other European authors have developed in the same years other unitary visions of the firm, also with a clear ethical, social, and human content; see, for example, Gutenberg (1969) in Germany, Bloch-Lainé (1963) in France, de Woot (1968) in Belgium, and Valero (1962) in Spain. The unitary character of these concepts is important because CSR cannot be developed separately according to business functions.

20 In this framework, the "private" interpretation of the "traditional" corporate responsibilities is, in some form, unnecessary, unlike what occurred, for example, in Spain during the first years of the twentieth century (Argandoña et al., 2010a), where a developed legal and institutional framework and a more or less clear definition of the responsibilities of the different actors were lacking.

21 The diversity of the "promoters" of "old" and "new" CSR is also important because they have different ideologies, interests, conceptions, and principles; they endorse and support different variants of CSR (peace and labor rights, or environmental issues in emerging markets, for instance, against the interests of workers in advanced countries), and they set different standards and control mechanisms (working consensus against transparency, accountability, reporting, etc.). All this underlines, once again, the need to pay attention to the variety of CSR contents and the contextualization of its definition.

22 As in the case of Swedish "model," the existence of a kind of "national agreement" in Germany poses an interesting question for the interpretation of CSR: is a firm responsible for the duties that have been imposed on it by a national model or agreement in which it has not participated? We think that the answer is in the affirmative: the national "model" or "agreement" is a specific concretion of how companies in these countries, in dialog with other social actors, define their social functions and responsibilities. What the debate about the "new" CSR shows is that the list of social responsibilities is longer than the "old" ones.

23 This was reflected, for example, in the creation of the German stock company as a societal institution, as it mandates the managers not only to focus on profit but also on societal goals, in sharp contrast to the AngloAmerican models: two laws (of 1937 and 1976) spell out that the managers have to protect the interests of parties other than the owners.

24 Berthoin Antal et al. (2010) also point out that "most scholars acting in the field [of CSR] in Germany in this period [since the 1990s] had little or no awareness of the work that had been conducted in earlier decades. By overlooking the extent of "implicit" CSR in Germany, they mistakenly saw the country as a blank spot on the CSR landscape."

25 It can be also a legal category, but we are talking here of responsibilities whose origin is not law or regulation.

\section{Acknowledgments}

We thank Professor Brian Husted for his useful comments to a draft of this paper; as usual, he is not responsible of the omissions and mistakes left. Antonio Argandoña acknowledges also the help of the "la Caixa" Chair of Corporate Social Responsibility and Corporate Governance of IESE Business School.

\section{References}

Adams, C. A., W. Y. Hill and C. B. Roberts: 1998, 'Corporate Social Reporting Practices in Western Europe: Legitimating Corporate Behaviour?', British Accounting Review 30, 1-21.

Anonymous: 2006, 'Giving a Damn About CSR. Corporate Social Responsibility Definitions from Our Online Survey', Accountancy Ireland 38(3), 48.

Argandoña, A.: 2009, 'Can Corporate Social Responsibility Help to Understand the Credit Crisis?', Presented to the Conference "Business Ethics and the Credit Crisis", University of North Carolina, Charlotte, March 31-April 1, 2009.

Argandoña, A., C. M. Moreno and J. M. Solà: 2010a, 'Social Responsibility and Social Security: The Foundation of Caja de Pensiones para la Vejez y de Ahorros', Journal of Business Ethics, this issue.

Argandoña, A., C. M. Moreno and J. M. Solà: 2010b, 'Corporate Social Responsibility in the First Years of 
Caja de Pensiones para la Vejez y de Ahorros', Journal of Business Ethics, this issue.

Berthoin Antal, A., M. Oppen and A. Sobczak: 2010, '(Re)discovering Social Responsibility of Business in Germany', Journal of Business Ethics, this issue.

Bloch-Lainé, F.: 1963, Pour una reforme de l'entreprise (Seuil, Paris).

Business in the Community: n.d., 'Corporate Responsibility (CR)', www.bitc.org.uk. Accessed 25 Sept 2009.

Carroll, A. B.: 1979, 'A Three-Dimensional Conceptual Model of Corporate Performance', Academy of Management Review 4(4), 497-505.

De Geer, H., T. Borglund and M. Frostenson: 2010, 'Reconciling CSR with the Role of the Corporation in Welfare States - the Problematic Swedish Example', Journal of Business Ethics, this issue.

De George, R. T.: 1982, Business Ethics (Macmillan, New York, NY).

de Woot, P.: 1968, Pour une doctrine de l'entreprise (Seuil, Paris).

Doh, J. and T. Guay: 2006, 'Corporate Social Responsibility, Public Policy, and NGO Activism in Europe and the United States: An Institutional Stakeholder Perspective', Journal of Management Studies 43(1), 47-73.

Eshleman, A.: 2004, 'Moral Responsibility', in E. N. Zalta (ed.), Stanford Encyclopedia of Philosophy, www.plato. stanford.edu/entries/moral-responsibility. Accessed July 2006.

European Commission: 2001, Green Book. Promoting a European Framework for Corporate Social Responsibility (European Commission, Brussels).

Fischer, J. M.: 1999, 'Recent Work on Moral Responsibility', Ethics 110, 93-139.

Fisher, J. M. and M. Ravizza: 1998, Responsibility and Control. A Theory of Moral Responsibility (Cambridge University Press, Cambridge, England).

Frederick, W. C.: 2006, Corporation, Be Good! The Story of Corporate Social Responsibility (Dog Ear Publishing, Indianapolis, IN).

Glover, J.: 1970, Responsibility (Routledge and Kegan Paul, London).

Gutenberg, E.: 1969, Grundlagen der Betriebwirtschaftslehre, Vol. 3 (Springer Verlag, Berlin).

Habisch, A., J. Jonker, M. Wegner and R. Schmidpeter (eds.): 2005, Corporate Social Responsibility Across Europe (Springer Verlag, Berlin).

Hart, H. L. A.: 1968, Punishment and Responsibility (Oxford University Press, New York, NY).

Hiss, S.: 2009, 'From Implicit to Explicit Corporate Social Responsibility', Business Ethics Quarterly 19(3), 433-451.
International Chamber of Commerce: 2002, Business in Society: Making a Positive and Responsible Contribution (ICC, Paris).

Jonas, H.: 1984, The Imperative of Responsibility. In Search of an Ethics for the Technological Age (University of Chicago Press, Chicago, IL).

Maignan, I. and D. A. Ralston: 2002, 'Corporate Social Responsibility in Europe and the U.S.: Insights from Businesses' Self-Presentations', Journal of International Business Studies 33, 497-514.

Matten, D. and J. Moon: 2008, "Implicit" and "Explicit" CSR: A Conceptual Framework for a Comparative Understanding of Corporate Social Responsibility', Academy of Management Review 33(2), 404-424.

Midttun, A., K. Gautesen and M. Gjolberg: 2006, 'The Political Economy of CSR in Western Europe', Corporate Governance 6(4), 369-385.

Oshana, M.: 1997, 'Ascriptions of Responsibility', American Philosophical Quarterly 34, 71-83.

Painter-Morland, M.: 2006, 'Redefining Accountability as Relational Responsiveness', Journal of Business Ethics 66(1), 89-98.

Pava, M.: 2008, 'Why Corporations Should Not Abandon Social Responsibility', Journal of Business Ethics 83(4), 805-812.

Pereboom, D.: 1999, Living Without Free Will (University of Vermont Philosophy Department, Burlington).

Pérez López, J. A.: 1993, Fundamentos de la dirección de empresas (Rialp, Madrid).

Rusconi, G. and S. Signori: 2010, 'Ethical Thinking in Traditional Italian Economia Aziendale and the Stakeholder Management Theory: The Search for Possible Interactions', Journal of Business Ethics, this issue.

Scanlon, T. M.: 1998, What We Owe to Each Other (Harvard University Press, Cambridge, MA).

Sison, A.: 2010, 'From CSR to Corporate Citizenship. Anglo-American and Continental European Perspectives', Journal of Business Ethics, this issue.

Smith, A. M.: 2007, 'On Being Responsible and Holding Responsible', The Journal of Ethics 11, 465-484.

Strawson, P. F.: 1962, 'Freedom and Resentment', Proceedings of the British Academy 48, 187-211.

Takala, T. and P. Pallab: 2000, 'Individual, Collective and Social Responsibility of the Firm', Business Ethics $A$ European Review 9(2), 109-118.

Thomas, G. and M. Nowak: 2006, 'Corporate Social Responsibility: A Definition', GSB Working Paper No. 62, Curtin University of Technology, Perth.

Valero, A.: 1962, 'Estructura de la empresa', Nuestro Tiempo March, 351-364. 
Vogel, D. J.: 2005, The Market for Virtue: The Potential and Limits of Corporate Social Responsibility (Brookings Institution Press, Washington, DC).

Waldkirch, R.W., M. Meyer and K. Homann: 2010, 'Accounting for the Benefits of Social Security and the Role of Business: Four Ideal Types and the Different Heuristics', Journal of Business Ethics, this issue.

Wallace, R. J.: 1994, Responsibility and the Moral Sentiments (Harvard University Press, Cambridge, MA).

Watson, G.: 1996, 'Two Faces of Responsibility', Philosophical Topics 24, 227-248.

Weber, M.: 1921, 'Politik als Beruf, in Gesammelte Politische Schriften (Duncker \& Humboldt, Munich) (English version in H. H. Gerth and C. Wright Mills (eds.), From Max Weber: Essays in Sociology (Oxford University Press, New York, NY) 1946).

Welford, R. J.: 2003, 'Corporate Social Responsibility in Europe and Asia: Critical Elements and Best Practice', Journal of Corporate Citizenship 13, 31-47.

Welford, R. J.: 2005, 'Corporate Social Responsibility in Europe, North America, Asia. 2004 Survey Results', Journal of Corporate Citizenship 17, 33-52.
Williams, G.: 2006, 'Responsibility', in The Internet Encyclopedia of Philosophy, www.iep.utm.edu/r/responsi. htm. Accessed July 2006.

Zwetsloot, G. I. J. M.: 2003, 'From Management Systems to Corporate Social Responsibility', Journal of Business Ethics 44(2-3), 201-208.

Antonio Argandoña

IESE Business School,

University of Navarra, Av. Pearson 21, 08034 Barcelona, Spain E-mail: argandona@iese.edu

Heidi von Weltzien Hoivik Center for Ethics and Leadership, Norwegian School of Management, Nydalsveien 37, 0484 Oslo, Norway

E-mail: heidi.hovik@bi.no 